\title{
The study of the elemental composition of snow and morbidity of the population in industrial cities of the Irkutsk Region
}

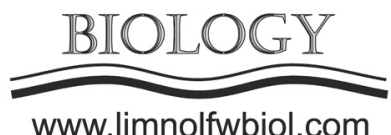

Onishchuk N.A., Netsvetaeva O.G., Molozhnikova E.V.

Limnological Institute, Siberian Branch of the Russian Academy of Sciences, Ulan-Batorskaya Str., 3, Irkutsk, 664033, Russia

ABSTRACT. This work presents the study of the elemental composition in the soluble fraction of snow from industrial cities of the Irkutsk Region (Angarsk, Irkutsk and Shelekhov). We detected tracer elements typical of snow in each of the cities. We also analysed morbidity in recent years and indicated the effect of air pollution on public health.

Keywords: snow, elemental composition, morbidity, Irkutsk Region

For several decades, some cities of the Irkutsk Region, including Angarsk, Irkutsk and Shelekhov, have been in the Priority List of the Russian cities with the highest air pollution. The List includes cities with a very high level of air pollution, which have air quality index of 14 or higher. This index characterises the level of chronic long-lasting air pollution. The share of the Irkutsk Region in air emissions is $10 \%$ of the total emissions from the Siberian Federal District and $3 \%$ of the emissions from Russia in general. Almost all industrial production, fossil fuel combustion, vehicles and other types of human activity lead to the anthropogenic dispersion of elements and heavy metals in the environment (Saet et al., 1990; Wiseman and Zerein, 2009).

Assessing the impact of environmental pollution on public health is one of the most relevant issues for environmental research. According to the World Health Organization (WHO), 91\% of the world's population lives in areas where air quality exceeds permissible WHO pollution levels.

We studied snow in three cities of the Irkutsk Region (Angarsk, Irkutsk and Shelekhov) as a total air quality index. Long-term studies have revealed that the general trend in the distribution of elemental concentrations in the snow of these cities remains (Fig.). This characterises the common sources in the formation of the elemental composition of the snow in the cities, e.g. fuel combustion (primarily coal) and motor vehicles. However, some elements showed significant differences in concentrations.

The snow from Shelekhov had elevated concentrations of lithium, beryllium, aluminium, nickel, and antimony. The long-term average concentration of aluminium in Shelekhov was $5569 \mu \mathrm{g} /$ $\mathrm{dm}^{3}$, which is an order of magnitude higher than the concentrations in Angarsk of $570 \mu \mathrm{g} / \mathrm{dm}^{3}$ and Irkutsk of $108 \mu \mathrm{g} / \mathrm{dm}^{3}$. The high aluminium concentration in the snow from Shelekhov is due to atmospheric emissions from aluminium production. The snow from Angarsk had elevated concentrations of boron, chromium, manganese, iron, zinc, arsenic, selenium, strontium, molybdenum, cadmium, tungsten, and uranium. In Irkutsk, there were high concentrations of copper, barium, lead, and thorium. The high level of air pollution in the studied cities is one of the negative factors affecting public health (Table).

Angarsk is leading in the number of oncological diseases, and only in 2014, the incidence in Shelekhov was higher than in Angarsk. From 2010 to 2018, the malignancy rate increased by $18 \%$ in all studied cities. The incidence of cancer in the studied cities is higher by $30 \%$ than average in Russia. The petrochemical industry with high air emissions of a large number of pollutants is developed in Angarsk, which leads to a high malignancy rate. Aluminium and its compounds

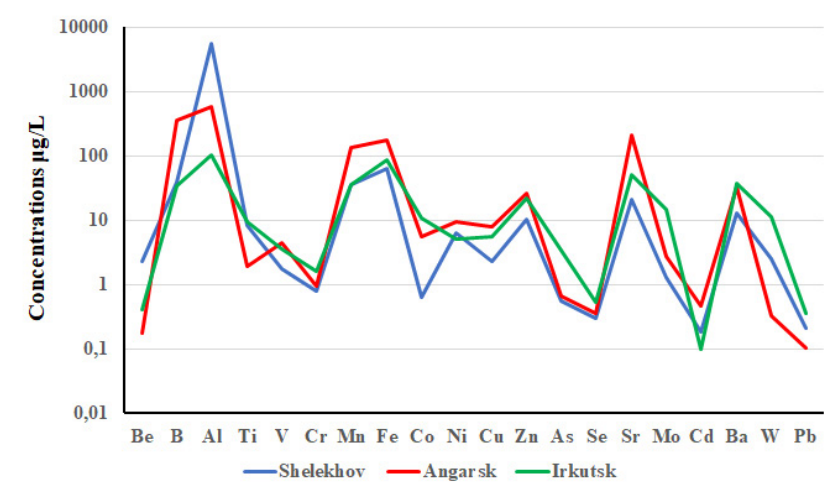

Fig. Elemental composition in the soluble fraction of snow from the cities of the Irkutsk Region in 2010-2018 
Table. Morbidity of the population in Irkutsk, Angarsk and Shelekhov in 2010-2018

\begin{tabular}{|c|c|c|c|c|c|c|c|c|c|}
\hline \multirow[t]{2}{*}{ City } & \multicolumn{9}{|c|}{ Morbidity by disease categories per 100 thousand people } \\
\hline & \multicolumn{9}{|c|}{ Malignant neoplasms } \\
\hline & 2010 & 2011 & 2012 & 2013 & 2014 & 2015 & 2016 & 2017 & 2018 \\
\hline Angarsk & 470.5 & 508.1 & 466.0 & 481.4 & 476.1 & 529.3 & 537.9 & 544.2 & 558.0 \\
\hline Irkutsk & 446.4 & 459.5 & 463.7 & 459.5 & 463.2 & 482.7 & 495.3 & 515.9 & 533.1 \\
\hline \multirow[t]{2}{*}{ Shelekhov } & 422.7 & 433.8 & 381.4 & 388.4 & 497.6 & 513.4 & 500.9 & 498.3 & 522.7 \\
\hline & \multicolumn{9}{|c|}{ Rheumatism } \\
\hline Angarsk & 97.4 & 93.6 & 91.2 & 96.5 & 79.8 & 50.1 & 66.1 & 70.9 & 62.6 \\
\hline Irkutsk & 141.7 & 153.0 & 156.2 & 160.5 & 103.6 & 96.3 & 195.7 & 200.1 & 191.4 \\
\hline \multirow[t]{2}{*}{ Shelekhov } & 255.2 & 168.5 & 210.0 & 221.1 & 295.1 & 177.3 & 258.2 & 246.1 & 253.1 \\
\hline & \multicolumn{9}{|c|}{ Asthma } \\
\hline Angarsk & 1312.4 & 1189.6 & 1374.7 & 1283.1 & 1121.4 & 952.9 & 941.9 & 850.3 & 795.0 \\
\hline Irkutsk & 1793.0 & 1892.6 & 1365.7 & 2079.9 & 2122.9 & 2147.9 & 2141.4 & 2301.5 & 2283.5 \\
\hline \multirow[t]{2}{*}{ Shelekhov } & 976.9 & 1087.0 & 1222.1 & 1369.0 & 1488.2 & 1404.7 & 1528.8 & 1640.0 & 1541.1 \\
\hline & \multicolumn{9}{|c|}{ Diseases of the nervous system } \\
\hline Angarsk & 5415.1 & 5144.6 & 6263.3 & 6825.4 & 7358.6 & 7888.2 & 6419.7 & 6533.1 & 3990.3 \\
\hline Irkutsk & 8005.6 & 8605.5 & 8719.3 & 9213.4 & 10210.4 & 10450.6 & 10750.3 & 10976.9 & 10931.1 \\
\hline Shelekhov & 8684.0 & 8583.8 & 15718.7 & 9342.8 & 9615.4 & 3474.4 & 7002.6 & 6432.9 & 6108.8 \\
\hline
\end{tabular}

are highly toxic compounds (toxicity class III), whose critical organs and systems are the central nervous system, the skeletal system and the respiratory system. One of the main signs of aluminium intoxication is a violation of the skeletal system (Shugaley et al., 2012). The incidence of rheumatism in Shelekhov is two times higher than in Angarsk in recent years and 1.2-1.3 times higher than Irkutsk. Until 2014, the cerebrovascular disease was high in Angarsk. After 2014, its high incidence is observed in Shelekhov. In Irkutsk, there is a high incidence of asthma and diseases of the nervous system.

\section{Conclusion}

Air pollution in the studied cities is one of the negative factors affecting public morbidity. The study of the elemental composition of snow revealed some toxic elements affecting public health. In all cities, there is a high malignancy rate, which is higher by $30 \%$ than in Russia as a whole.

This study was supported by the LIN SB RAS State Task No. 0345-2019-0008 and the RFBR grant No. 20-45-380024 r/a.

\section{References}

1. Saet Yu.E., Revich B.A., Yanin E.P. 1990. Geokhimiya okruzhayushchei sredy. Moscow: Nedra. (in Russian)

2. Wiseman C.L., Zereini F. 2009. Airborne particulate matter, platinum group elements and human health: a review of recent evidence. Science of the Total Environment 407: 2493-2500. DOI: 10.1016/j.scitotenv.2008.12.057

3. Shugaley I.V., Garabadzhiu A.V., Ilyushin M.A. et al. 2012. Some aspects of the influence of aluminum and its compounds on living organisms. Ekologicheskaya Khimiya [Ecological chemistry] 21: 172-186. (in Russian) 